\title{
NILAI MODERASI ISLAM DAN INTERNALISASINYA
}

\section{SEKOLAH}

\section{A. Hermawan}

Institut Agama Islam Negeri Purwokerto

Abstract:The growth of radical movement has been spread in education areas today, particularly in school. The growth is systematically need to be prevented. In Islamic educational context, the action that should be put is through internalization of Islamic moderation values in school. The Islamic moderation values that include tolerant, justice, balance (harmony), and equality can be fostered by education of Islamic religion (PAI) as the basic of the development. There are two important models that should be concerned with the internalization, i.e through official curriculum and hidden curriculum. Of course, the official curriculum should be the basic of the internalization, but it is not enough, it necessary to strengthen through hidden curriculum by construct the socio-cultural context that support to the transformation of Islamic moderation values in the school environment. If this process is runing well, the internalization of Islamic moderation values will reach to the optimal result and surely weaken the spread of Islamic radical movement. This article will explore and analyse the models of internalization especially on hidden curriculum in the school.

Keywords: Islamic moderation values, internalization, official curriculum, hidden curriculum.

Abstrak: Pertumbuhan gerakan radikal telah menyebar di bidang pendidikan saat ini, terutama di sekolah. Pertumbuhan secara sistematis perlu dicegah. Dalam konteks pendidikan Islam, tindakan yang harus dilakukan adalah melalui internalisasi nilai-nilai moderasi Islam di sekolah. Nilai-nilai moderasi Islam yang mencakup toleransi, keadilan, keseimbangan (harmoni), dan kesetaraan dapat dipupuk oleh pendidikan agama Islam (PAI) sebagai dasar pembangunan. Ada dua model penting yang harus diperhatikan dengan internalisasi, yaitu melalui kurikulum resmi dan kurikulum tersembunyi. Tentu saja, kurikulum resmi harus menjadi dasar internalisasi, tetapi tidak cukup, perlu untuk memperkuat melalui kurikulum tersembunyi dengan membangun konteks sosial-budaya yang mendukung transformasi nilai-nilai moderasi Islam di lingkungan sekolah. Jika proses ini berjalan dengan baik, internalisasi nilai-nilai moderasi Islam akan mencapai hasil yang optimal dan tentunya memperlemah penyebaran gerakan radikal Islam. Artikel ini akan mengeksplorasi dan menganalisis model-model internalisasi terutama pada kurikulum tersembunyi di sekolah.

Kata kunci: Nilai-nilai moderasi Islam, internalisasi, kurikulum resmi, kurikulum tersembunyi.

\section{A. PENDAHULUAN}




\section{Ajib Hermawan}

Kenyataan bahwa Indonesia merupakan negara yang plural tidak bisa dibantah lagi. Keragaman adalah bagian dari ciri khas Indonesia yang harus disikapi oleh setiap warga negara dengan cara yang tepat sehingga bisa menjadi warna yang mampu memperkaya khazanah peradaban bangsa. Meskipun keragaman telah menjadi realitas yang disadari oleh segenap warga bangsa, namun penyikapan yang tepat tersebut masih menjadi persoalan, apalagi ketika keragaman dan perbedaan tersebut terkait dengan keyakinan agama. Keyakinan terhadap agama yang dipeluk oleh seseorang acap kali menutup peluang terhadap adanya kebenaran pada keyakinan lainnya. Pada tahap ini, klaim terhadap kebenaran agamanya (truth claim) akan menjadi alat penghakiman (judgement) terhadap "kesesatan" pada keyakinan yang lain. Basis kesadaran teologis seperti ini hanya membutuhkan sedikit pemicu saja untuk merembet dan berkembang pada aspek sosial yang memunculkan intoleransi dan gerakan radikal.

Pada akhir-akhir ini, pemahaman terhadap Islam radikal terasa semakin menguat yang ditandai dengan banyaknya kasus intoleransi baik pada lingkungan masyarakat maupun di sekolah. Hal ini tentu saja menjadi persoalan yang harus segera diatasi karena dapat merusak konstruksi sosial masyarakat Indonesia yang sangat multikultur. Persoalan akan semakin rumit dan mengkhawatirkan ketika paham radikal dan intoleransi agama juga telah menjangkiti siswa di sekolah, karena merekalah yang nantinya menjadi penentu masa depan bangsa dan negara.

Sebuah penelitian yang dilakukan oleh Pusat Pengkajian Islam dan Masyarakat (PPIM) UIN Syarif Hidayatullah Jakarta pada 2017 terhadap siswa, mahasiswa, guru dan dosen di 34 provinsi di Indonesia menunjukkan bahwa, siswa dan mahasiswa memiliki kecenderungan pada pandangan keagamaan yang intoleran dengan persentase opini radikal sebesar 58,5\%, opini intoleransi internal 51,1\%, dan opini intoleransi eksternal 34,3\% (PPIM UIN Jakarta, 2017: 3). Data ini memberikan pemahaman kepada kita bahwa bibit radikalisme dan intoleransi benar-benar telah muncul dan menjangkiti siswa di sekolah. Pada bagian lain dari penelitian ini juga menunjukkan bahwa model pembelajaran PAI juga memiliki potensi untuk membentuk radikalisme siswa, sama dengan opini dan pemahaman radikal guru yang juga berpotensi menular terhadap para siswa.

Kondisi di atas memunculkan pertanyaan besar tentang bagaimana nilai-nilai moderasi Islam yang menjadi mainstream pemahaman agama Islam di Indonesia bisa mulai mendapatkan tantangan besar dari paham Islam radikal? Bagaimana sesungguhnya lembaga pendidikan mengambil peran dan memfasilitasi penyebaran dan penanaman nilai moderasi Islam? Tulisan ini akan menganalisis beberapa hal yang bisa dilakukan oleh sekolah dalam menginternalisasi nilai moderasi Islam dan memberikan perspektif penguatan yang bisa dijadikan alternatif dalam menanamkan ajaran Islam yang moderat.

\section{B. METODE}

Penelitian ini merupakan penelitian pustaka (library research), yaitu penelitian yang dilakukan untuk menggali dan menganalisis data yang bersumber dari dokumen yang tertulis (teks). Seluruh data yang menjadi bahan untuk melakukan kajian berasal dari teks atau naskah yang telah menjadi koleksi perpustakaan (Zed, 2204:2). Untuk memudahkan dalam pengumpulan data, maka sumber data dibagi menjadi sumber data 
utama dan sekunder. Sumber data utama adalah buku, artikel ataupun dokumen lainnya yang terkait secara langsung dengan tema utama dalam penelitian. Sedangkan sumber data sekunder adalah sumber data yang mendukung, melengkapi atau memperkuat dari data utama (Ibrahim, 2015: 68).

Proses analisis data menggunakan pendekatan analisis ini (content analysis), yaitu teknik yang digunakan untuk menarik kesimpulan dengan berupaya menemukan karakteristik pesan dari teks yang dilakukan secara objektif dan sistematis. Fokus kajian dalam penelitian ini ditopang dengan menggali sumber-sumber pustaka utama untuk kemudian ditelaah dengan melakukan kategorisasi berdasarkan tema atau topik yang sesuai. Kategorisasi dan tema-tema yang telah dipilah dihubungkan untuk dicari keterkaitan dan kemungkinan munculnya gagasan atau temuan baru sebagai hasil dari proses telaah terhadap wacana yang dikembangkan. Bagian akhir dari proses ini adalah penarikan kesimpulan berdasarkan analisis data yang telah dilaksanakan.

\section{NILAI MODERAT DALAM AJARAN ISLAM}

Dalam agama Islam, pesan tentang perbedaan dan keragaman dapat ditemukan dalam banyak ayat al-Qur'an dan hadits. Keanekaragaman sesungguhnya merupakan kehendak dari Allah itu sendiri (Shihab, 2007:52). Sehingga pemahaman tentang pluralitas seharusnya telah menjadi bagian yang menyatu dalam kesadaran teologis setiap muslim. Kesadaran tentang keragaman ini pada gilirannya juga akan mengarahkan pada pemahaman dan sikap moderat dalam beragama. Karena setiap perbedaan pasti akan memunculkan persinggungan dan gesekan. Namun dengan sikap yang moderat dalam beragama akan melihat perbedaan dan keragaman sebagai sebuah realitas yang tidak perlu dipertentangkan, namun justru dikelola dengan baik sehingga menjadi sumber kekayaan khazanah sosial budaya. Pada titik inilah kita bisa merasakan kebenaran bahwa perbedaan dan keragaman merupakan rahmat dan berkah bagi kehidupan.

Konsep moderasi dalam Islam dikenal dengan istilah wasathiyah yang bersumber dari al-Qur'an sendiri. Al-Qur'an menyebut umat Islam sebagai ummah wasatha (al-Baqarah: 143). Dalam kerangka ini sesungguhnya bersikap moderat merupakan karakter utama dari seorang muslim (Suharto, 2014: 88). Menurut alQardhawi, wasathiyah adalah sesuatu yang memerlukan hak yang sepatutnya, yaitu dengan memberikan hak yang sewajarnya dengan mengambil jalan tengah agar tidak melampaui batas-batas syariat Islam (Qardhawi, 1997: 10). Dalam konteks Indonesia, menurut Masdar Hilmy, sikap moderat dapat tercermin dalam karakter sebagai berikut; 1) penyebaran ajaran Islam melalui ideologi non kekerasan, 2) mengadopsi cara hidup modern dengan segala derivasinya, termasuk teknologi, demokrasi, HAM, dan sejenisnya, 3) penggunaan cara berpikir rasional, 4) memahami Islam dengan pendekatan kontekstual, dan 5) penggunaan ijtihad dalam mencari solusi terhadap persoalan yang tidak ditemukan justifikasinya dalam al-Qur'an dan hadits (Hilmy, 2013: 25).

Untuk menopang konsep dan sikap moderat, setidaknya ada empat nilai dasar yang perlu dikembangkan dan diinternalisasikan melalui proses pendidikan. Keempat nilai dasar tersebut adalah toleran (tasamuh), keadilan (i'tidal), keseimbangan 
(tawazzun), dan persamaan. Secara singkat penjelasan tentang keempatnya adalah sebagai berikut:

\section{Toleran}

Dalam bahasa arab, istilah toleran bermakna tasamuh yang berarti sifat dan sikap tenggang rasa atau saling menghargai antar sesama manusia, walaupun pendirian atau pendapatnya berbeda (bertentangan) dengan pendiriannya sendiri. Secara etimologi, toleransi adalah kesabaran, ketahanan emosional, dan kelapangan dada. Sebagai makhluk sosial, manusia tidak akan pernah bisa untuk tidak membutuhkan orang lain, semua manusia tentu saling membutuhkan. Oleh karena itu antara satu manusia dengan manusia yang lainnya harus saling memperhatikan dan saling tolong menolong dalam kebajikan dan dalam berbagai aspek kehidupan, mulai dari aspek sosial, ekonomi, budaya, kemasyarakatan dan aspek kehidupan kemanusiaan lainnya. Jalinan persaudaraan dan toleransi antara umat beragama sama sekali tidak dilarang oleh Islam, selama masih dalam tataran kemanusiaan dan kedua belah pihak saling menghormati hak-haknya masing-masing. Toleransi meniscayakan sebuah cakrawala yang luas untuk memahami orang lain, karena dengan pemahaman tersebut akan memudahkan jalan untuk mengenali dan menjalin kerjasama. Salah satu jalan untuk mencapai peradaban toleransi ini adalah melalui inklusifisme (Misrawi, 2010: 178). Sikap inklusif akan mengajarkan kepada kita tentang kebenaran yang bersifat universal sehingga dengan sendirinya juga akan mengikis sikap eksklusif yang melihat kebenaran dan kemuliaan hanya ada pada diri dan pihak kita sendiri. Kebenaran sangat mungkin sekali ada dan dimiliki oleh orang lain.

\section{Keadilan}

Hampir semua agama memiliki konsep dasar tentang keadilan dan dijadikan sebagai standar kebajikan yang diajarkan kepada pemeluknya. Meskipun demikian, mungkin saja terjadi perbedaan dalam pemahamannya, dalam mempersepsinya dan dalam mengembangkan visinya, sesuai dengan prinsip-prinsip teologisnya. Secara umum pengertian adil mencakup; tidak berat sebelah, berpihak kepada kebenaran, objektif dan tidak sewenang-wenang. M. Quraish Shihab mengemukakan bahwa kata adil pada awalnya diartikan dengan sama atau persamaan, itulah yang menjadikan pelakunya tidak memihak atau berpihak pada yang benar (Shihab, 1998: 111).

\section{Keseimbangan}

Keseimbangan (tawazun) yaitu sikap berimbang atau harmoni dalam berkhidmad demi terciptanya keserasian hubungan antar sesama umat manusia dan antara manusia dengan Allah swt. Dengan prinsip tawazun, berusaha mewujudkan integritas dan solidaritas sosial umat Islam. Dengan tawazun, muncul keseimbangan antara tuntutan-tuntutan kemanusiaan dan ketuhanan, muncul konsep penyatuan antara tatanan duniawi dan tatanan agama, juga muncul adanya harmoni antara hak dan kewajiban. Prinsip tawazun, yakni menjaga keseimbangan dan keselarasan, sehingga terpelihara secara seimbang antara kepentingan dunia dan akhirat, kepentingan pribadi dan masyarakat, dan kepentingan masa kini dan masa datang. Keseimbangan di sini adalah bentuk hubungan yang tidak berat sebelah (menguntungkan pihak tertentu dan merugikan pihak 
yang lain). Tetapi, masing-masing pihak mampu menempatkan dirinya sesuai dengan fungsinya tanpa mengganggu fungsi dari pihak yang lain. Hasil yang diharapkan adalah terciptanya hidup yang dinamis.

\section{Kesetaraan}

Islam memandang bahwa semua manusia adalah sama (setara), tidak ada perbedaan satu sama lain dengan sebab ras, warna kulit, bahasa atau pun identitas sosial budaya lainnya. Prinsip kesetaraan ini merupakan konsekuensi dari nilai toleransi yang dicapai melalui inklusifitas. Sikap inklusif akan mengajarkan kepada kita tentang kebenaran yang bersifat universal sehingga dengan sendirinya juga akan mengikis sikap eksklusif yang melihat kebenaran dan kemuliaan hanya ada pada diri dan pihak kita sendiri. Kebenaran sangat mungkin sekali ada dan dimiliki oleh orang lain. Pemahaman ini juga akan mengarahkan kita pada kesetaraan, dan egaliterianisme. Satu-satunya pembeda secara kualitatif pada diri manusia adalah ketakwaannya kepada Allah.

\section{PENDIDIKAN AGAMA ISLAM SEBAGAI BASIS PENGEMBANGAN}

Terdapat temuan yang menarik sekaligus mengejutkan dari kajian yang dilakukan oleh Pusat Pengkajian Islam dan Masyarakat (PPIM) UIN Jakarta pada tahun 2016 yang melakukan penelitian tentang dugaan adanya muatan ajaran intoleransi dan kekerasan pada materi buku ajar mapel PAI terbitan Kementerian Pendidikan dan Kebudayaan yang digunakan di sekolah (SD, SMP dan SMA). Temuan dari penelitian ini antara lain;

1. Adanya ajaran intoleransi dalam buku ajar PAI yang disampaikan dalam bentuk menyalahkan pendapat atau praktik ibadah yang berbeda, mengunggulkan satu pendapat tanpa memberikan pembanding, memberikan gambaran atau penjelasan yang bersifat negatif terhadap umat lain dan tidak disertai penegasan bahwa Islam mengajarkan untuk menghormati kebebasan keyakinan dan anjuran untuk menjaga kerukunan antar umat beragama.

2. Negara tidak menjadikan produksi buku teks PAI tersebut sebagai bagian dari politik kebudayaan nasional untuk pembangunan karakter bangsa.

3. Terdapat ketidaktegasan visi, misi, dan tujuan buku-buku teks PAI tersebut, sehingga tidak memuat ajaran dan pesan Islam yang rahmatan lil 'alamiin sesuai dengan nilai-nilai kebangsaan Indonesia, sehingga buku-buku teks tersebut tidak jelas, tidak koheren, dan atau bahkan kontradiktif dengan keislaman Indonesia. (Suharto, 2017: 170-171).

Catatan penting terhadap hasil penelitian PPIM UIN Jakarta tersebut adalah adanya persoalan besar terkait penyebaran konsep moderasi Islam melalui pendidikan agama di sekolah. Jika selama ini gerakan deradikalisasi begitu gencar dipromosikan oleh pemerintah dalam upaya meminimalisir penyebaran paham keagamaan yang radikal, maka apa yang terjadi merupakan sebuah ironi. Beberapa penulis dan penerbit buku PAI yang memiliki peran besar dalam penyusunan muatan kurikulum ternyata tidak memiliki kesadaran dan pemahaman yang cukup untuk ikut berperan dalam 
mempromosikan Islam moderat. Hal ini megindikasikan ada yang salah dalam proses tersebut.

Pendidikan merupakan media yang paling efektif untuk menyemai dan menyebarkan sebuah paham atau ideologi. Dalam konteks ini, maka sangat tepat jika dikatakan bahwa untuk menyebarluaskan dan menanamkan nilai-nilai moderasi Islam maka pendidikan menjadi pilihan utama. Oleh karenanya, lembaga pendidikan seharusnya bisa menjadi garda terdepan sebagai media untuk mengenalkan Islam yang toleran, ramah, dan moderat (Arifin, 2014: 416). Menurut Muhammad Ali, ideologi Islam moderat dapat disemai melalui model pendidikan pluralis multikulturalis. Wawasan pluralis-multikultural dalam pendidikan agama merupakan dasar bagi para siswa agar mampu menghargai perbedaan, menghormati secara tulus, komunikatif, terbuka, dan tidak saling curiga, di samping dalam kerangka meningkatkan iman dan takwa. Pendidikan pluralis-multikultural tidak berarti mengajarkan anak didik untuk menjalankan agama sesuai kehendaknya sendiri, tanpa tanggung jawab dan ketulusan, tetapi justru mengajarkan untuk taat beragama, tanpa menghilangkan identitas keagamaan masing-masing. Wajah agama yang ditampilkan pendidikan pluralismultikultural adalah agama yang moderat dan ramah (Ali, 2003:102).

Melalui kerangka ini, Pendidikan Agama Islam (PAI) yang diajarkan di sekolah tetap bisa dijadikan sarana utama untuk menanamkan nilai moderasi Islam melalui konstruksi pendidikan Islam pluralis-multikulturalis sebagaimana ditawarkan oleh Ali. Temuan penelitian yang dilakukan oleh PPIM UIN Jakarta tentu saja menjadi catatan penting adanya kelemahan dari sisi konten muatan materi pembelajaran. Namun, hasil temuan dari penulis sendiri dalam penelitian terhadap buku ajar PAI untuk SMA yang dilakukan pada tahun 2015 menunjukkan hasil yang berbeda. Pada penelitian tersebut, penulis menemukan bahwa pembahasan-pembahasan pada setiap bidang keilmuan (Aqidah, Akhlak, Fiqih, al-Qur'an dan Hadits, dan Sejarah Islam) sudah mengarahkan pada pemahaman agama Islam sebagaimana yang diyakini dan diamalkan umat Islam di Indonesia. Nilai-nilai dasar keislaman yang diajarkan, meskipun belum tajam sekali, namun sudah mengakomodasi nilai-nilai Islam moderat (Hermawan, 2015: 78).

Ini artinya bahwa optimisme terhadap PAI sebagai media untuk menyemai nilai moderasi Islam tetap harus dipegang kuat. Yang perlu dilakukan adalah pembenahan pada beberapa aspek agar penguatan terhadap proses internalisasi ini dapat mencapai hasil yang maksimal. Dengan mengadopsi konsep yang dikembangkan oleh James Banks, pada wilayah praksis Kasinyo Harto menawarkan konsep pengembangan PAI sebagai basis pengembangan nilai moderasi Islam, yaitu (Harto, 2014: 75-77);

1. Pada aspek integrasi muatan/isi. Materi PAI harus merefleksikan cara pandang atau perspektif yang beragam. Cara yang bisa ditempuh adalah melalui beberapa pendekatan yang dilakukan oleh guru dalam menambahkan beberapa unit atau topik secara khusus yang berkaitan dengan materi multikultural.

2. Dari aspek konstruksi pengetahuan, PAI harus mampu membantu peserta didik untuk memahami beberapa perspektif dan merumuskan kesimpulan yang dipengaruhi disiplin pengetahuan yang mereka miliki.

3. Pada aspek pengurangan prasangka, guru PAI mengupayakan beragam cara dan metode yang dikembangkan agar peserta didik mampu berperilaku positif dalam menghadapi perbedaan. 
4. PAI harus mengandung dimensi pendidikan yang adil dan setara. Strategi yang dapat dilakukan adalah dengan menerapkan model pembelajaran yang berbentuk kerja sama (cooperative learning), bukan dengan model yang kompetitif (competitive learning).

5. PAI harus mengandung dimensi pemberdayaan budaya sekolah dan struktur sosial. Keragaman latar belakang peserta didik harus mampu dikelola dengan baik oleh guru PAI sebagai bahan untuk membentuk kultur sekolah sebagai landasan untuk menyusun struktur sosial dalam lingkungan sekolah.

\section{E. MODEL INTERNALISASI NILAI MODERASI ISLAM DALAM PENDIDIKAN}

Dalam konteks pendidikan, sebuah nilai atau ideologi dapat diinternalisasikan melalui beberapa proses atau langkah yang sistematis dalam sebuah lembaga pendidikan, sebagaimana halnya dengan nilai moderasi Islam. Dengan mengadopsi konsep yang dikembangkan oleh Gerald L. Gutek tentang ideologi pendidikan, nilai moderasi Islam bisa diinternalisaskan melalui tiga bentuk, yaitu; 1) melalui penentuan kebijakan dan tujuan pendidikan, 2) di dalam formulasi kurikulum itu sendiri, dan 3) di dalam penyampaian nilai-nilai yang tersembunyi dalam hidden curriculum (Suharto, 2017: 167). Satu hal yang harus diperhatikan bahwa dalam menerapkan ketiga aspek tersebut lembaga pendidikan atau sekolah harus menjadikan nilai moderasi Islam sebagai nilai utama layaknya ideologi pendidikan yang dianut.

Setiap lembaga pendidikan ataupun sekolah tentu memiliki visi, misi, dan tujuan yang spesifik sebagai panduan dalam menentukan program dan arah institusi. Perumusan visi, misi dan tujuan kelembagaan didasarkan pada nilai, filsafat, atau ideologi yang dianut dan dipegang oleh lembaga tersebut. Di sinilah posisi penting nilai moderasi Islam sebagai basis untuk menentukan dan mengembangkan tujuan dan kebijakan sekolah. Dalam konteks pendidikan Islam yang dikembangkan di Indonesia, Abuddin Nata memberikan sepuluh karakteristik nilai moderasi Islam dengan istilah yang disebutnya sebagai Islam rahmatan lil alamin, yaitu; 1) pendidikan Islam damai, yaitu pendidikan yang diarahkan kepada pengembangan pribadi manusia untuk memperkuat rasa hormat kepada hak asasi manusia dan kebebasan mendasar, 2) mengembangkan pendidikan kewirausahaan serta membangun kemitraan antara dunia pendidikan dengan dunia usaha dan industri, 3) mengembangkan ilmu-ilmu sosial yang profetik, 4) memasukkan materi toleransi beragama, 5) mengajarkan Islam moderat yang menjadi Islam mainstream di Indonesia, 6) mengembangan pendidikan yang seimbang antara kekuatan penalaran dan pengembangan wawasan intelektual, penguasaan sains dan teknologi (head), pengembangan spiritualitas dan akhlak mulia (heart), dan keterampilan bekerja vokasional (hand), yang antara satu dan lainnya saling menopang, 7) mencetak ulama yang intelek dan intelek yang ulama, 8) pendidikan yang menjadi solusi bagi problem-problem pendidikan saat ini seperti masalah dualisme dan metodologi pembelajaran, 9) peningkatan mutu pendidikan secara komprehensif, dan 10) peningkatan kemampuan bahasa asing, terutama Inggris dan Arab (Nata, 2016: 1014). 
Dari kesepuluh karakteristik pendidikan Islam di atas, poin 1, 3, 4 dan 5 dapat dijadikan acuan dalam merumuskan dan mengembangkan kebijakan dan tujuan sekolah yang mencerminkan nilai-nilai moderasi Islam. Keempat poin di atas (pendidikan Islam damai, ilmu sosial profetik, toleransi beragama, dan Islam moderat) mencerminkan ruh Islam yang ramah dan solutif terhadap persoalan-persoalan ketegangan religiusideologis. Secara kelembagaan, sekolah perlu untuk memasukkan karakteristik tersebut dalam perumusan tujuan sekolah agar arah (visi) sekolah yang sesuai dengan karakter Islam Indonesia bisa mewujud dan memberikan pengaruh kuat bagi peserta didik.

Untuk menilai kekuatan sebuah kurikulum kita bisa melihat dari materi yang terkandung di dalamnya dan diajarkan kepada para peserta didik (muatan kurikulum). Penguatan kurikulum pada orientasi muatan ini bisa dengan mengkaji sumber rujukan atau referensi utama pada teks-teks bahan ajar, mengevaluasi kategori-kategori atau tema-tema tertentu yang berkaitan dengan nilai moderasi Islam. Dari proses ini maka akan memunculkan tawaran literatur atau sumber belajar baru yang sesuai dengan nilainilai yang diinginkan, yaitu moderasi Islam. Muatan kurikulum yang sudah sesuai dengan nilai yang diinginkan pun belumlah cukup jikak tidak diimbangi dengan model pembelajaran inovatif yang mampu mengeksplorasi makna moderasi Islam sehingga dapat memperkuat internalisasi melalui proses pembelajaran. Di sinilah peran guru sebagai fasilitator menjadi sangat signifikan dalam menanamkan nilai moderasi Islam.

Penguatan orientasi muatan kurikulum dengan nilai moderasi Islam dapat diupayakan dengan meminjam konsep yang ditawarkan oleh Zakiyuddin Baidhawi dalam konteks pendidikan agama berwawasan multikultural. Ada lima langkah yang bisa dilakukan, yaitu; Pertama, melakukan kritik dan mengkaji ulang terhadap kurikulum PAI yang bersifat ekslusif. Kedua, mengintegrasikan informasi atau sumber tentang orang-orang terkemuka dan artefak kultural dari berbagai kelompok keagamaan dalam kurikulum utama. Ketiga, mengintegrasikan hari besar dan tokoh keagamaan pada substansi materi dan pengetahuan pada kurikulum pendidikan agama Islam. Keempat, mengeksplorasi berbagai sumber keagamaan dari beragam perspektif untuk memperluas basis pengetahuan agama peserta didik. Kelima, mengintrodusir isu-isu sosial keagamaan untuk menanamkan kesadaran multikultural (sikap moderat) dalam kurikulum pendidikan agama Islam (Baidhawi, 2007: 112-113).

Dari langkah-langkah di atas terlihat bahwa muatan kurikulum PAI dengan nilai moderasi Islam tidak hanya bersandar pada pengambil kebijakan atau decision maker kurikulum saja, namun juga peran sentral dari guru (agama). Oleh sebab itu kompetensi dan pemahaman guru terhadap nilai-nilai moderasi Islam menjadi prasyarat penting dalam pencapaian tujuan kurikulum. Dalam sebuah proses pembelajaran, kurikulum tidak hanya berhenti pada buku teks atau bahan ajar, namun juga bagaimana seorang guru mentransformasikan nilai kepada siswa melalui pembelajaran yang mencerminkan nilai-nilai tersebut.

Bentuk ketiga dari konsep yang ditawarkan Gutek adalah melalui hidden curriculum. Moderasi Islam sebagai sebuah nilai dapat dikembangkan proses internalisasinya melalui kurikulum tersembunyi (hidden curriculum). Sebagai penunjang kurikulum formal, kurikulum tersembunyi dapat memberikan pengaruh yang sangat kuat dalam internalisasi nilai-nilai tertentu. Hal ini karena sifat dari hidden curriculum yang tidak terprogram atau didesain secara sistematis namun mengalir 
melalui interaksi dan komunikasi sebagai bagian dari kultur sosial yang berkembang di kelas dan lingkungan sekolah. Penulis akan memaparkan secara khusus persoalan ini pada bagian akhir paper.

Secara teoretis, sebagai sebuah nilai, moderasi Islam juga dapat diinternalisasikan dalam beragam model kurikulum. Dengan meminjam konsep dari Daniel Schugurensky tentang pendidikan multikultural, setidaknya ada delapan model kurikulum yang dapat digunakan mengintegrasikan nilai moderasi Islam (Schugurensky, 2002: 3-6), yaitu;

1. Kurikulum tertulis (prescribed/intended curriculum). Ini adalah kurikulum resmi yang dipakai oleh sekolah atau lembaga pendidikan. Di dalamnya mencakup muatan dan metode pembelajaran, tujuan dan alokasi waktu yang dibutuhkan. Melalui kurikulum model inilah nilai moderasi Islam harus diintegrasikan secara komprehensif, karena model ini merupakan kurikulum resmi (official curriculum) yang setiap sekolah harus memilikinya. Pada kurikulum model ini pulalah orientasi, arah dan filosofi pendidikan lembaga tersebut terartikulasikan.

2. Kurikulum yang diajarkan (taught curriculum). Maksudnya adalah bahwa apa yang secara aktual dilakukan oleh guru di dalam kelas. Pada situasi tertentu meskipun kurikulum tertulis telah disusun sedemikian baik sehingga mengintegrasikan nilai moderasi Islam, namun sangat mungkin terjadi penyimpangan dalam implementasinya, sehingga terjadi "gap" antara kurikulum tertulis dengan kurikulum yang diajarkan. Penyimpangan ini bisa terjadi karena kompetensi guru yang tidak cukup untuk mentransformasikan nilai yang ingin dicapai. Kompetensi moderasi guru ini bisa dipengaruhi oleh pandangan politik, ideologi, arah keagamaan, latar belakang pendidikan dan lainnya. Oleh karena itu, sekolah harus bisa memastikan bahwa guru PAI yang mengajar benar-benar memiliki visi Islam moderat dan adanya supervisi dari pempinan sekolah.

3. Kurikulum yang diujikan (tested curriculum). Dalam sebuah desain kurikulum tentu saja ada sistem evaluasi yang dikembangkan sebagai alat ukur untuk menilai ketercapaian tujuan. Implementasi kurikulum yang diujikan dapat dilihat pada proses ujiannya yang bisa berbentuk tertulis atau lisan, terstandarisasi atau diversifikasi, pilihan ganda atau essay. Moderasi Islam sebagai nilai ketercapaiannya dapat dilihat tidak hanya pada aspek kognitif saja, namun justru pada afektif. Oleh karena itu juga perlu dilihat apakah sistem evaluasi yang dikembangkan telah mengakomodir aspek afektif dan psikomotorik dari nilai moderasi Islam atau tidak.

4. Kurikulum yang dilaporkan (reported curriculum). Kurikulum yang dilaporkan adalah laporan tentang apa yang peserta didik pahami terkait dengan topiktopik tertentu dalam merespon pertanyaan khusus yang dibuat oleh pihak berwenang dalam pendidikan. Dalam hal ini adalah laporan tentang pengetahuan peserta didik tentang ajaran Islam dalam paradigma moderat. Ada kelemahan pada kurikulum yang dilaporkan ini, yaitu bahwa kurikulum ini 
tidak sepenuhnya merefleksikan keyakinan dan pengetahuan peserta didik secara aktual. Penyebabnya karena, pertama sangat mungkin pertanyaan yang diberikan tidak disusun secara layak, dan kedua apa yang dilaporkan sebagai jawaban acap kali tidak mencerminkan apa yang diyakini dan dipahami oleh peserta didik, apalagi jika menyangkut hal sensitif terkait ideologi atau perspektif tertentu.

5. Kurikulum tersembunyi (hidden curriculum). Kurikulum tersembunyi merupakan sesuatu yang diajarkan di luar kurikulum yang tertulis, sesuatu yang bisa melampaui dari materi yang diajarkan. Kurikulum ini dapat diekspresikan dalam lingkungan sekolah, dalam suasana ruang kelas dengan penataannya, dalam metode pembelajaran, dalam interaksi guru-peserta didik, dalam interaksi antar sesama peserta didik, dan dalam dinamika "yang tidak terlihat" lainnya. Dalam hal ini sekolah dan seluruh civitas akademikanya dapat secara bersama mengkonstruksi konteks sekolah dalam suasana kultur dan sosial yang mendukung penerapan nilai moderasi Islam. Jika proses ini bisa berjalan dengan baik, maka akan menjadi penunjang yang sangat kuat bagi pencapaian tujuan yang telah ditetapkan dalam kurikulum tertulis.

6. Kurikulum yang dihilangkan (missing curriculum). Kurikulum yang dihilangkan adalah hal-hal yang dikeluarkan atau dilarang, secara bebas ataupun tidak dari proses pembelajaran. Dalam kajian tentang pendidikan agama Islam dengan nilai moderat di dalamnya sangat mungkin terdapat muatan-muatan yang perlu dihilangkan, isu-isu yang disensor, ataupun gagasan "yang dibungkam" yang berpotensi menghambat integrasi dan internalisasi nilai moderasi Islam.

7. Kurikulum luar (external curriculum). Kurikulum luar merujuk pada apa yang dipelajari oleh peserta didik di luar kelas (sekolah), bisa dari pelajar lainnya, ataupun dari sumber-sumber lain seperti keluarga, media, pemuka agama, tetangga, teman dan lainnya dengan cara yang beragam pula. Pihak-pihak yang berasal dari luar dapat memberikan penguatan dalam proses internalisasi nilai moderasi Islam, meskipun pada sisi lain juga berpotensi membawa nilai yang kontradiktif.

8. Kurikulum yang dipelajari (learned curriculum). Kurikulum yang dipelajari adalah apa yang peserta didik benar-benar pelajari dari keseluruhan pengalaman pada akhir proses studi, meskipun sangat sulit untuk mengidentifikasi dengan pasti jumlah variabel yang terlibat dalam proses tersebut. Sesungguhnya apa yang peserta didik pelajari berbeda dengan apa yang tertulis, diajarkan bahkan yang diujikan. Oleh sebab itu, kurikulum yang dipelajari ini memiliki aspek subjektifitas yang sangat bergantung pada pengalaman pribadi peserta didik dalam mencerna dan meresapi nilai-nilai moderasi Islam.

Delapan model kurikulum yang ditawarkan oleh Schugurensky merupakan model yang saling menopang dan saling mendukung. Tentu saja jika setiap sekolah mampu mengembangkannya dalam kerangka internalisasi nilai moderasi Islam maka akan menjanjikan hasil yang optimal. Satu catatan penting dari analisis terhadap modelmodel kurikulum tersebut adalah bahwa dalam proses internalisasi nilai ataupun 
ideologi, kurikulum tertulis sebagaimana telah diterapkan di semua sekolah tidaklah cukup untuk mencapai hasil yang maksimal. Masih dibutuhkan pendekatan dan model lainnya yang akan menunjang keberhasilannya.

\section{F. HIDDEN CURRICULUM SEBAGAI PENGUAT}

Kajian terhadap analisis yang diberikan baik oleh Gerald L. Gutek maupun Daniel Schugurensky di atas mengantarkan kita pada satu pemahaman bahwa proses internalisasi nilai moderasi Islam dalam lembaga pendidikan atau sekolah paling tidak harus diupayakan melalui dua model utama, yaitu kurikulum formal (formal curriculum) dan kurikulum tersembunyi (hidden curriculum). Peranan kurikulum tersembunyi tidak bisa dilepaskan dalam proses pendidikan. Kenyataan yang terjadi adalah kurikulum tersembunyi merupakan hasil dari sesuatu yang tidak direncanakan dan pengalaman alamiah peserta didik. Hidden curriculum tidak hanya berkaitan dengan pembelajaran yang ada di kelas saja, melainkan berkaitan dengan pengalaman siswa yang dapat dilihat, didengar, dan dirasakan oleh peserta didik yang dapat mengubah perilaku dan hasil belajar siswa.

Ada beberapa definisi yang diberikan oleh para ahli pendidikan tentang hidden curriculum, di antaranya Henry Giroux yang secara generik menjelaskan bahwa hidden curriculum merupakan "unstated norms, values and beliefs that transmitted to students through the underlying structure of meaning in both the formal content as well as the social relation of school and classroom life" (Giroux, 1983: 47). Menurut Michael W. Apple, hidden curriculum dapat diartikan sebagai norma-norma dan nilai-nilai yang secara implisit, tapi efektif, diajarkan sekolah kepada siswa yang biasanya tidak dicantumkan di dalam tujuan guru mengajar secara formal. Kurikulum semacam ini justru yang sebenarnya memiliki kontribusi yang signifikan bagi upaya melestarikan ideologi secara hegemonik (Apple, 2004: 78-79).

Dua pengertian di atas menjelaskan bahwa nilai, norma, keyakinan, ataupun ideologi dapat diinternalisasikan dan ditransfer kepada peserta melalui sebuah proses yang tanpa didesain secara formal dan tertulis terlebih dahulu. Upaya internalisasi tersebut lebih mengandalkan pada relasi sosial dan pembentukan budaya yang mengedepankan aspek interaksi dan komunikasi antar warga sekolah. Internalisasi nilai model inilah justru yang akan dapat membentuk karakter kuat pada peserta didik. Oleh sebab itu, agar proses internalisasi nilai moderasi Islam dapat berjalan dengan baik dan memperoleh hasil maksimal, sekolah perlu menciptakan dan membudayakan sikap toleran, respek terhadap orang lain, menghargai perbedaan, membangun struktur sosial sekolah yang demokratis dan berkeadilan, persamaan hak, dan nilai-nilai lain yang berkorelasi dengan semangat Islam moderat baik di dalam kelas maupun di lingkungan sekolah lainnya.

Jika sekolah mampu membuat konteks sosial yang mendukung tersemainya nilai moderasi Islam, maka pada posisi ini keberadaan hidden curriculum akan berfungsi sebagai pendukung dan penguat bagi keberlangsungan kurikulum formal (tertulis). Ketika dalam kurikulum formal dari sisi muatan konsep tentang perbedaan, toleransi, demokrasi, kesetaraan telah dijelaskan lengkap dengan metode yang perlu diterapkan 


\section{Ajib Hermawan}

oleh guru dalam sebuah pembelajaran, maka tidak menjamin sepenuhnya bahwa peserta didik akan memahami secara penuh dan mempengaruhi sikap dan perilaku dalam kehidupan sehari-hari. Namun hasilnya tentu akan berbeda jika peserta didik menemukan dan mengalami sendiri bagaimana lingkungan yang demokratis terbangun di ruang kelas, toleransi dan keseteraan dirasakan melalui struktur sosial budaya yang ada di sekolah. Sehingga kurikulum tersembunyi sesungguhnya mampu untuk mengarahkan atau merubah sikap dan perilaku peserta didik (Wren, 1999: 595).

\section{G. SIMPULAN}

Semakin massifnya penyebaran gerakan gerakan radikal dalam beragama menjadi tantangan nyata bagi umat Islam di Indonesia yang secara sosio kultural memiliki paham Islam yang moderat. Dalam konteks pendidikan, tentu menjadi tugas bersama untuk membendung radikalisasi agama (Islam) yang terjadi di sekolah (lembaga pendidikan) sekaligus menyebarluaskan nilai moderasi Islam yang sesuai dengan karakter Islam Indonesia kepada peserta didik.

Ada dua aspek yang perlu menjadi perhatian dalam proses internalisasi nilai moderasi Islam pada sekolah dengan menggunakan Pendidikan Agama Islam sebagai basis pengembangannya, yaitu melalui kurikulum formal (tertulis) dan kurikulum tersembunyi (hidden curriculum). Tentu saja kurikulum formal menjadi tumpuan utama dalam menginternalisasikannya. Namun dengan hanya mengandalkan kurikulum formal tentu tidak cukup, karena adanya beberapa potensi penyimpangan dan kelemahan di dalamnya. Oleh karena itu, lembaga pendidikan (sekolah) perlu memperkuatnya dengan mengkonstruksi konteks sosio kultural sekolah melalui hidden curriculum. Jika kedua aspek ini mampu digerakkan secara bersama dan terintegrasi, maka upaya penyemaian dan internalisasi nilai moderasi Islam kepada peserta didik akan semakin optimal. Pada sisi lain, proses ini akan mempersempit dan melemahkan penyebaran dan pengembangan pemahaman Islam yang eksklusif, radikal dan intoleran.

\section{DAFTAR PUSTAKA}

Ali, Muhammad. 2003. Teologi Pluralis-Multikultural: Menghargai Kemajemukan, Menjalin Kebersamaan. Jakarta: Penerbit Buku Kompas

Al-Qardhawi, Yusuf., 1997. Wasatiyyah al-Islam. Islam Moderate Legislation for Progressive Nation. Terj. Ahmad Umar Hisyam \&Muhammad Higab. Cairo: alAzhar

Apple, William W. 2004. Ideology and Curriculum. New York: Routledge Falmer

Arifin, Syamsul., 2014. "Membendung Arus Radikalisasi di Indonesia", dalam ISLAMICA: Jurnal Studi Keislaman, Vol. 8, Nomor 2

Baidhawi, Zakiyuddin., 2007. Pendidikan Agama Berwawasan Multikultural. Jakarta: Erlangga

Giroux, Henry A. 1983. Theory and Resistance in Education: A Pedagogy for The Opposition. Massachussets: Bergin \& Garvey Publisher Inc.

Harto, Kasinyo. 2014. Model Pengembangan Pendidikan Agama Islam Berbasis Multikultural. Jakarta: Raja Grafindo Persada 
Hermawan, M. A. 2015. Islam Inklusif dalam Kurikulum Pendidikan Agama Islam SLTA dalam Jurnal Penelitian Agama (JPA), Vol. IX, No. 1, Jan-Jun

Hilmy, Masdar. 2013. "Whither Indonesia's Islamic Moderatism? A Reexamination on the Moderate Vision of Muhammadiyah and NU", dalam Journal of Indonesian Islam, Vol. 07, Number 01, June

Ibrahim, 2015, Metodologi Penelitian Kualitatif, Bandung: Alfabeta

Misrawi, Zuhairi. 2010. Al-Qur'an Kitab Toleransi: Tafsir Tematik Islam Rahmatan lil Alamin, Jakarta: Pustaka Oasis

Nata, Abuddin. 2016. "Islam Rahmatan Lil Alamin sebagai Model Pendidikan Islam Memasuki ASEAN Community", Makalah Kuliah Tamu Jurusan Pendidikan Agama Islam Fakultas Ilmu Tarbiyah dan Keguruan UIN Maulana Malik Ibrahim Malang Senin, 7 Maret

PPIM UIN Jakarta. 2017. Api dalam Sekam: Keberagaman Gen Z (Survei Nasional tentang Sikap Keberagamaan di Sekolah dan Universitas di Indonesia. Jakarta: UIN Jakarta

Schugurensky, Daniel. 2002. "The Eight Curricula of Multicultural Citizenship Education", dalam Multicultural Education. Fall 10.1

Shihab, M. Quraish. 2007. Secercah Cahaya Ilahi: Hidup Bersama Al-Qur'an. Bandung: Mizan

Suharto, Toto. 2014. Gagasan Pendidikan Muhammadiyah dan NU sebagai Potret Pendidikan Islam Moderat di Indonesia, dalam ISLAMICA: Jurnal Studi Keislaman. Volume 9, Nomor 1, September

-. 2017. "Indonesiasi Islam: Penguatan Islam Moderat dalam Lembaga Pendidikan Islam di Indonesia", dalam Al-Tahrir, Vol. 17, No. 1 Mei

Wren, David J. 1999. "School Culture: Exploring The Hidden Curriculum", dalam ADOLESCENCE, Vol. 34, No. 135, Fall

Zed, Mestika. 2004. Metode Penelitian Kepustakaan, Jakarta: Yayasan Obor Indonesia 